\title{
ELÄMÄ ON OPPIMISTA - OPPIMINEN ON TAISTELUA
}

itkälle edennyt elinikäisen oppimisen politiikka alkaa enenevästi mui-
tuttaa Foucaultin luonnehdintaa poliitikasta sodankäynnin jatkami-
sena rauhan nimissä, puhumattakaan tarkkailun ja rankaisemisen muotojen sofistikoitumisesta. Toki kasvatuksen on aina uskolteltu toimivan hyvän puolesta pahaa vastaan, mutta kun markkinat ja valtiovarainministeriön järjestelyosasto hoitavat arvokeskustelun, joutuvat kasvatusinstituutiot ja -toimijat alituisesti huolehtimaan pahan eri muotojen nitistämisestä.

Aika kultaa muistot: arviointi-Suomea edeltäneessä teknokraattisessa hyvinvointi-Suomessa niin hallitsijat kuin kasvattaja-alamaiset tuntuivat vielä kantavan huolta yhteiskunnallisesta oikeudenmukaisuudesta ja ihmisten tasa-arvoisesta osallistumisesta ja osallisuudesta yhteiseen hyvään ja sen rakentamiseen. Näyttämölle oli kuitenkin jo saapunut ylikansallisen talouden ja politiikan uusi muunnos: globaali markkinatalous ja ylikansallinen hallinta. Kasvatuksen ja koulutuksen alalla aikakauden muutos usein paikannetaan OECD:n (läntisten teollisuusmaiden dominoima taloudellinen yhteistyö- ja kehittämisjärjestö, jonka lähtökohtana on markkintalouden, pluralistisen demokratian ja ihmisoikeuksien edistäminen -http:// www.oecd.org) selvityksiin ja suosituksiin. OECD toimii jäsenmaiden ylikansallisena politiikka-agendan ja liiketoiminnan edistämisen työkaluna, jonka keskeisenä tehtävänä on koulutuspoliittinen vaikuttaminen. Suomen kannalta toinen merkittävä aikakautta muokkaava tekijä on Euroopan Unioni, joka vahvistaa eurooppalaisen talousalueen kilpailukykyä globaaleilla markkinoilla harmonisoituvan koulutus-, sosiaali- ja työvoimapolitiikan avulla.

Sosialistisen järjestelmän romahtaminen, globaalin markkinatalouden jäätävä henkäys ja kotoisen eliitin hätäinen käänne voittajien suuntaan pisti suomalaiset polvilleen 1990-luvulla. Hyvinvointivaltion edistämisen nimissä kehitellyistä koulutusreformeista tuli kasvatuksen kaikilla asteilla ja alueilla säästö- ja markkinoistamiskuureja. Talvisodan henki kannatteli kansaa aikansa, mutta ilman mentaalista muutosta päälle pukattua vaihdetta ei pitkään voi perustella. Koulutuksesta ja oppimisesta oli muotoiltava tuotos, jonka arvo voidaan mitata markkinakriteerein. Kasvatuksen raaka-aine-, tuotanto- ja jakelukustannukset sekä epärelevantit pyrkimykset ja toiminnot on minimoitava, tieto- ja viestintätekniikan käyttö maksimoitava. Oppimistuloksia mittaavan PISA-tutkimuksen ohella OECD on käynnistänyt selvityksiä myös koulutuksen pitkäaikaisvaikutuksista: oppimishaluisuudesta, työ- ja kansalaiskuntoisuudesta, terveys- ja sosiaalisesta käyttäytymisestä. EU:n jäsenenä Suomi on puolestaan etulinjassa eurooppalaisia laatujärjestelmiä päiväkodeista yliopistoihin asti. Ne puolestaan edellyttävät eurooppalaisia kvalifikaatiojärjestelmiä ja standardeja. Näin mahdollisestaan inhimillisen voimavaran optimaalinen hyödyntäminen EU-Euroopassa. 
Mitä ja ketä arviointi koskee? Opetushallituksen teettämissä koulutuk-sen arvioinneissa, lukuisissa opinnäytetöissä ja tutkimusraporteissa oppilaitosten johtotehtävissä ja koulutushallinnossa toimivat näyttävät pitävän arviointia johtamisen välineenä. Useimmat riviopettajat ja -kasvattajat haaveilevat vielä arvionnin alistamisesta pedagogisen kehittämisen tueksi tai kyynisesti pelkäävät sen - paitsi syövän aikaa pedagogiselta perustehtävältä - myös johtavan tehokkuuden ja erinomaisuuden teatteriin. Monen muun tavoin olen ollut mukana eri tahojen auliisti rahoittamissa erilaisissa arviointihankkeissa, arviointitutkimuksissa ja itse arviointitoiminnan kehittämishankkeissa. Raportteja ja niiden yhteenvetoja lienevät eri organisaatioiden, hallitusten, ministeriöiden ja EU:n kellarit pullollaan. Kuka niitä jaksaa lukea ja miksi, kohtahan on jo seuraava arviointikierros alkamassa.

rviointi ei lienekään kovin tärkeää tuotostensa takia, vaan talviso-
dan hengen ylläpitämiseksi. Ulkoisesti EU-Eurooppa koulii huippu-
osaajien sotajoukkoa taisteluun globaalien markkinoiden ylivoimasta, sisäisesti jäsendivisioonat motivoidaan rahallisin kepein ja porkkanoin sekä johtajien ylennyksin ja palkkioin. Suomalaiset koulutuksen tarjoajat virtaviivaistavat tutkimus-, kehittämis- ja innovaatiotoimintansa profiileja ja ottavat löysät pois liikaväestön sopeuttamisesta ja rauhoittamisesta. Oppilaitosten sisäiset mestaruussarjat pitävät porukat ahkerina peilien edessä, kehittämisen kehittämisessä ja idolien takahuoneissa. Opetusteknologisten innovaatioiden toivotaan kääntävän opetuksen ja kasvatuksen välttämättömän pahan asiakastyytyväisyyden voitoksi. Todellisuus on valitettavasti tarua ihmeellisempi ja vaikkapa kasvatustieteellisen tutkimuksen ja koulutuksen sisäisen taistelun julmuus joskus parempi osoitus aikakauden luonteesta kuin tuhat koulutuksen arvioinnin akateemista kritiikkiä. Uskomattoman usein akateemista uraa tehdään ja asemaa oikeutetaan mitätöimällä, häpäisemällä ja hyväksikäyttämällä niitä, jotka ovat heikoimpia uhkaamaan vahvempiaan tai vaarantamaan tieteellisen tutkimuksen ja koulutuksen näkymättömiä standardeja. Keisarien vaatetukselle sen sijaan löytyy aina ihailijoita.

Ankarimmat elinikäisen oppimisen taistelut käytäneen kasvattajien ja kasvajien sisäisillä tantereilla. Kasvaako sisälläni häpeä ja viha kelpaamatonta ja toisinajattelevaa itseä kohtaan, jolle ei koskaan ole luvassa maanpäällistä eikä siten taivaallistakaan pelastusta? Luikinko käpykaartilaisena hakkuuaukeiden kätköihin vai joudunko “oppiminen vapauttaa”-leirien kanta-asiakkaaksi? Vai käynkö eespäin rohkeena hehkuvin rinnoin, taistelutorvi kun soi, kohti arviointien viitoittamaa tietä, sillä onhan nyt vanhallekin kaunista kuolla joukkojen eessä? Politiikkatieteilijä Aristoteles arveli aikoinaan, että ihmisen onnellisuutta voi luotettavasti arvioida vasta kuoleman hetkellä, jolloin voi punnita onnellisuuden ehtojen - hyveellisen toiminnan ja sen ulkoisten edellytysten - täyttymistä. Olisiko näin myös arvioinnin ja arviointitutkimuksen laita? 